\title{
Plant flavonoids as angiotensin converting enzyme inhibitors in regulation of hypertension
}

\author{
B.W. Nileeka Balasuriya and H.P. Vasantha Rupasinghe
}

Department of Environmental Sciences, Nova Scotia Agricultural College, PO Box 550, Truro, Nova Scotia B2N 5E3, Canada

Corresponding author: H.P. Vasantha Rupasinghe, PhD, Tree Fruit Bio-product Research Program, Department of Environmental Sciences, Nova Scotia Agricultural College, P.O. Box 550, Truro, Nova Scotia, Canada B2N 5E3

Submission date: March 6, 2011; Acceptance date: May 6, 2011; Publication date: May 8, 2011

\section{$\underline{\text { Abstract }}$}

Background: Angiotensin converting enzyme (ACE) is a key component in the renin angiotensin aldosterone system (RAAS) which regulates blood pressure. As the over expression of RAAS is associated with vascular hypertension, ACE inhibition has become a major target control for hypertension. The research on potential ACE inhibitors is expanding broadly and most are focused on natural product derivatives such as peptides, polyphenolics, and terpenes. Plant polyphenolics are antioxidant molecules with various beneficial pharmacological properties. The current study is focused on investigating and reviewing the ACE inhibitory property of fruit flavonoids. An apple skin extract (ASE) rich in flavonoids, the major constituents of the extract and their selected metabolites were assessed for the ACE inhibitory property in vitro. It is important to investigate the metabolites along with the flavonoids as they are the constituents active inside the human body.

Objective: To investigate whether flavonoids, flavonoid rich apple extracts and their metabolites could inhibit ACE in vitro.

Method: The samples were incubated with sodium borate buffer $(30 \mu \mathrm{L}, \mathrm{pH} 8.3), 150 \mu \mathrm{L}$ of substrate (Hip-His-Liu) and ACE $(30 \mu \mathrm{L})$ at $37{ }^{\circ} \mathrm{C}$ for $1 \mathrm{~h}$. The reaction was stopped by addition of $150 \mu \mathrm{L}$ of $0.3 \mathrm{M} \mathrm{NaOH}$. The enzyme cleaved substrate was detected by making a fluorimetric adduct by adding $100 \mu \mathrm{L}$ of o-phthaladehyde for $10 \mathrm{~min}$ at room temperature. Reaction was stopped by adding $50 \mu \mathrm{L}$ of $3 \mathrm{M} \mathrm{HCl}$. Fluorescence was measured by using a FluoStar Optima plate reader at excitation of $350 \mathrm{~nm}$ and emission of $500 \mathrm{~nm}$. 
Results: The extract and the compounds showed a concentration dependant enzyme inhibition. Increasing concentrations from $0.001 \mathrm{ppm}$ to $100 \mathrm{ppm}$ of ASE showed an increment of $29 \%$ to $64 \%$ ACE inhibition. The $\mathrm{IC}_{50}$ (concentration of test compound which gives $50 \%$ enzyme inhibition) values of ASE, quercetin, quercetin-3-glucoside, quercetin-3-galactoside, cyanidin-3galactoside were $49 \mu \mathrm{g} / \mathrm{mL}, 151 \mu \mathrm{M}, 71 \mu \mathrm{M}, 180 \mu \mathrm{M}, 206 \mu \mathrm{M}$, respectively. The major constituents of the ASE that were tested separately showed effective ACE inhibition. From the three metabolites tested, only quercetin-3-glucuronic acid showed concentration dependant ACE inhibition. The ACE inhibition of $0.001 \mathrm{ppm}$ to $100 \mathrm{ppm}$ of quercetin-3-glucuronic was in the range of $43 \%$ and $75 \%$ and the $\mathrm{IC}_{50}$ value was $27 \mu \mathrm{M}$.

Conclusion: The results demonstrated that flavonoids have a potential to inhibit ACE in vitro and the inhibitory property varies according to type of sugar moiety attached at C-3 position. The results also revealed that the major contributing compounds of ASE for ACE inhibition belong to flavonoids. Among the tested compounds, the lowest $\mathrm{IC}_{50}$ value is associated with the quercetin3-glucuronic acid, a major in vivo metabolites of quercetin and its glycosides. The results suggest that certain dietary flavonoids may possess properties of blood pressure regulation.

\section{Key words:}

Hypertension, renin angiotensin system (RAS), angiotensin converting enzyme (ACE), flavonoids, apple

\section{Background}

Hypertension is a common progressive disorder leading to several chronic diseases such as cardiovascular disease, stroke, renal disease and diabetes. One-quarter of the world's adult population is afflicted by hypertension, and this is likely to increase to $29 \%$ by 2025 [1]. Life style changes, physical exercise, intake of healthy diets are some common issues associated with reducing the risk of hypertension. However, at critical stages drugs are essential. Therefore, it is of great importance to discover natural therapeutics for prevention and cure.

The pathogenesis of hypertension could be due to many reasons. For example, increased activity of renin angiotensin aldosterone system (RAAS), kalikerenin kinin system and sympathetic nervous system, and genetic influence are specified [2]. Among them over activation of RAAS (Fig. 1) is significant [3]. Angiotensin converting enzyme (ACE) plays a significant role in RAAS, by converting the precursor angiotensin I into angiotensin II which is the peptide responsible in triggering blood pressure increasing mechanisms. Therefore, inhibition of ACE is a promising way of controlling over expression of RAAS.

ACE inhibitory drugs are first class therapeutics since decades. Captopril ${ }^{\circledR}$, Lisinopril ${ }^{\circledR}$, Enalpiril $^{\circledR}$, and Rampiril ${ }^{\circledR}$ are some examples for drugs targeted as ACE inhibitors. However, the 
prolong use of the drugs could initiate adverse side effects like dizziness, coughing, and angioneuretic edema [4]. New alternatives have been explored extensively as replacements of these drugs. Most of the researches have been targeted at bioactive compounds from natural resources. Peptides [5], anthocyanins [6], flavonols [7], triterpenes [8] are some examples. The objective of this review is to assess the potential of plant flavonoids to use as ACE inhibitors in regulation of hypertension.

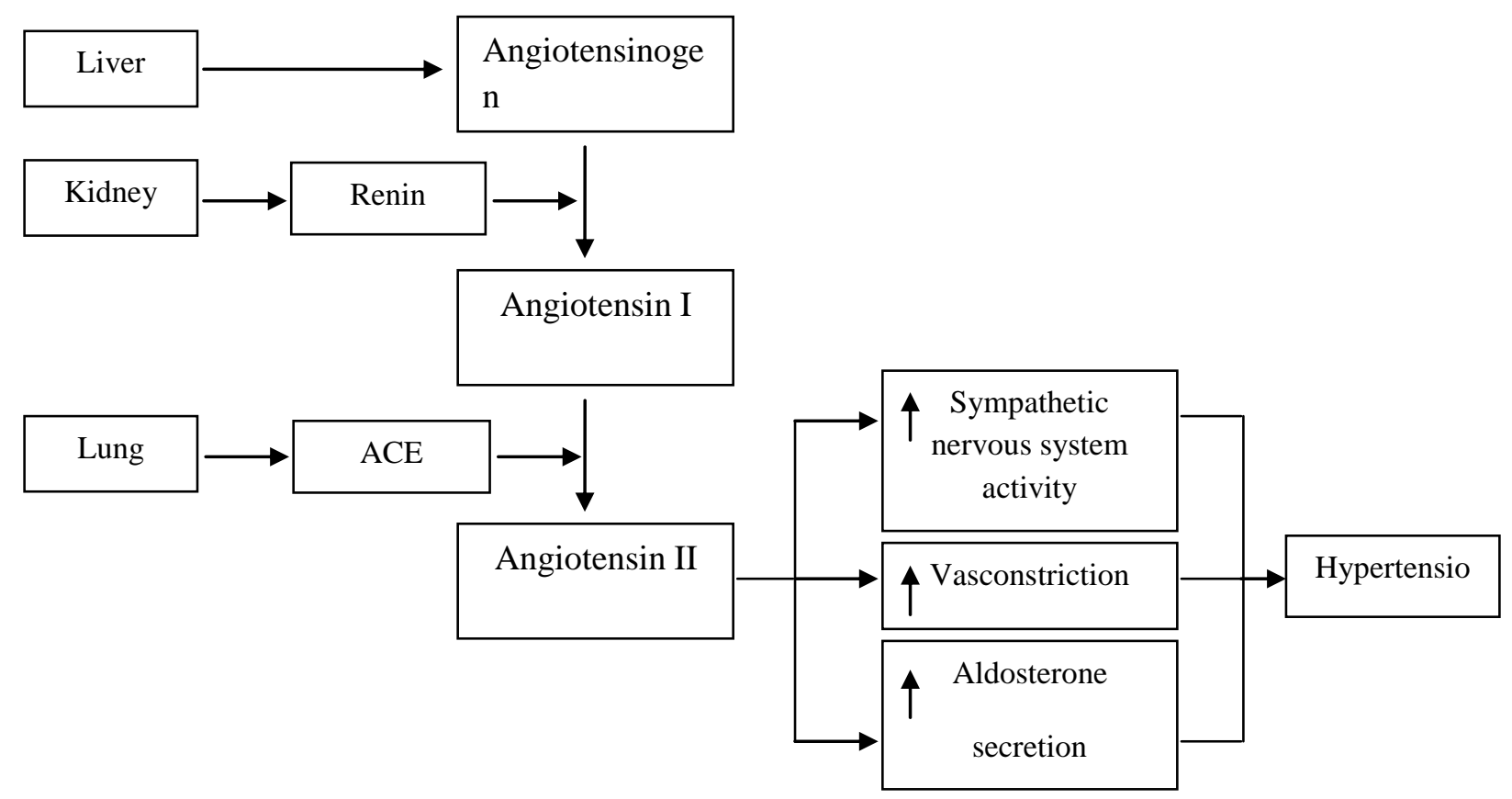

Fig. 1: Renin angiotensin aldosterone system (RAAS)

\section{ACE inhibition}

\section{ACE}

ACE is a dipeptidyl carboxypeptidase with a zinc atom. The enzyme has a less substrate specificity in vitro. ACE consists of a single polypeptide chain containing two domains: $\mathrm{N}$ and C. There are two catalytic sites in each of these domains [9]. The highest concentrations of ACE are present in the lung capillaries. As well, ACE is present in renal proximal tubules, gastrointestinal tract, cardiac tissues and brain tissues [10]. It exists as a membrane bound enzyme as well as a circulatory or globular enzyme [9].

\section{Assessment of Enzyme Inhibition}

There are number of methods used in detection of ACE inhibition. Among them are spectrophotometric, fluorometric, high-performance liquid chromatographic (HPLC), radiochemical and electrophoresis methods $[10,11]$. As there is less substrate specificity for 
ACE, several substrates have employed for in vitro enzyme inhibitory studies. Two commonly used substrates for spectrophotometric and HPLC analysis of ACE inhibitory activity are hippuryl-L-histidyl-L-leucine (HHL) and $\mathrm{N}$-(3-[2-furyl]acryloyl-phenylala glycy L glycine (FAPGG) $[12,13]$. HHL could be used in fluorescence detection methods of ACE inhibition along with fluorescing agents such as $o$-pthaldehyde [10]. The conversion of internally quenched fluorogenic substrates are reported to be very sensitive in detection of ACE inhibition. $O$ Aminobenzoylglycyl-p-nitro-phenylalanylproline [14] and abz-peptidyl-Eddnp (Abz: ortho amino benzoic acid. Eddnp: 2,4-dinytrophenyl ethylenediamine) are two examples of flurogenic substrates [10].

\section{Natural ACE Inhibitors}

Different types of natural food derived compounds have been investigated on their ACE inhibitory properties. Food protein derivatives are a major group of compounds investigated as potential ACE inhibitors. Food proteins can be divided into three categories as animal-derived, plant-derived and microorganism-derived peptides. Animal-derived category includes peptides from milk, meat, fish and eggs [15]. Casein, whey protein hydrolysates from milk, ovokinin from eggs are reported to be effective ACE inhibitors in both in vivo and in vitro studies [15, 16]. Meat and fish proteins are hydrolyzed using different enzymes like chymases, and the resulting fractions are subjected in determining ACE inhibitory properties. Among the fish species used for deriving ACE inhibitory peptides are bonito, sardine, salmon, hake and tuna [17, 5]. Plantderived peptides have also been identified from different sources including soybean, flaxseed, sunflower, rice, and corn $[18,19,12]$. There is less evidence on microorganism-derived peptides. Secondary metabolites produced in plants are another group of natural compounds which are identified as potential ACE inhibitors. Some terpenoids and polyphenolic compounds including flavonoids, hydrolysable tannins, xanthones, procyanidins, caffeolyquinic acid derivatives are found to be effective as natural ACE inhibitors [20, 21]. Most studies have showed that plant extracts rich in phytochemicals found to be effective in ACE inhibition. However, identification of compounds specifically inhibit ACE is lacking in most of these investigations.

\section{Flavonoids as ACE inhibitors}

Flavonoids are the largest group of polyphenolic compounds found in higher plants [22]. Tea, wine, apples, onions, grapes, and oranges are some foods rich in flavonoids. The biosynthesis of flavonoids occurs in higher plants through the shikimic acid and malonic acid pathways [23]. The common structure of flavonoids is comprised of two phenyl rings (A and $\mathrm{C}$ rings) joined with three carbons which make a closed pyran ring structure (B ring) (Fig. 2) [24]. Based on the structural differences, flavonoids are further subdivided into six sub-groups namely flavanones, flavones, flavonols, flavan-3-ols, anthocyanins and isoflavones [24]. The highly diverse structures of flavonoids show numerous functions in biological systems. In plants, flavonoids contribute to: insect attraction and repulsion through colour of leaves, fruits and flowers; 
protection against viral, fungal and bacterial infections and UV light; nodulation in legume roots, etc. [25]. Flavonoids are effective antioxidants in plants as well as in animals [22]. Flavonoids are identified as potential risk reducing components in the diet for cardiovascular disease, various cancers, neurodegenerative diseases, etc. [25]. For example, quercetin-3-O-glucoside, a flavonoid compound ubiquitous in fruits, has shown protective effect on human neuroblastoma cells (SH-SY5Y) against oxidative stress by a membrane injury recovery mechanism that is involved in up-regulation of genes involved in lipid and cholesterol synthesis [26].

The ability to use flavonoids as ACE inhibitors in regulating blood pressure had been studied during the past decades and most of them have proved to be effective in suppressing the activity of ACE $[6,7,27]$. The specificity of flavonoid sub-groups in inhibiting ACE would be discussed separately.

\section{Anthocyanins}

Anthocyanins are water soluble plant pigments giving rise to red, blue and purple colours of fruits and vegetables. In plants, they occur as anthocyanidins (aglycone form, Fig. 2) and then conjugate with sugars to form anthocyanins [24]. Anthocyanins have shown ACE inhibition in vitro. Delphinidin-3- $O$-sambubiosides and cyanidin-3- $O$-sambubiosides isolated from Hibiscus (Hibiscus sabdariffa) extracts had inhibited $\mathrm{ACE}$ in a dose dependant manner [6]. The $\mathrm{IC}_{50}$ values of anthocyanins were found to be in 100 to $150 \mu \mathrm{M}$ range (Table 1) [6]. Similarly, cyanidin-3-O- $\beta$-glucoside isolated from rose species (Rosa damascene) inhibited ACE in vitro. However, other flavonols isolated from rose extract were not effective ACE inhibitors when compared to cyanidin-3-O- $\beta$-glucoside [27]. Bilberry (Vaccinium myrtillus) extracts rich in major anthocyanins i.e. cyanidin, delphinidin and malvidin, were investigated on their effect on ACE in a human umbilical vein endothelial cell (HUVEC) culture model and the ACE activity had been significantly reduced after incubation of cells with bilberry extracts [28]. Dietary administration of anthocyanins-rich (cyanidin-3-glucosides, cyanidin-acyl-glucoside and peonidin-acyl-glucoside) purple corn, purple sweet potato and red radish to spontaneously hypertensive rats (SHR) had decreased the systolic and mean blood pressure [29]. The mechanisms behind the reduction of blood pressure by anthocyanins were reported due to their antioxidant activity, preservation of endothelial nitric oxide, and prevention of serum lipid oxidation but ACE inhibition was not found [29].

The observed ACE inhibitory activity of anthocyanins in vitro could be explained by the metal chelating ability of flavonoids with hydroxyl groups at 3, 5, 7 and 3', 4' positions [27, 28]. The planer structure of the anthocyanin molecules also indicated to be important in metallopeptidase inhibition [6]. In animals, the absorption rate and the corresponding metabolites of anthocyanins affect on the enzyme inhibition. However, a strong correlation between ACE inhibition in vitro and animal model systems has not been reported.

\section{Flavan-3-ols (Flavanols)}


Flavanols have a saturated C-ring with a hydroxyl group at the C-3 position (Fig. 2). They do not exist in glycosylated form as the other flavonoids. They can be found in both monomer form (catechins) and polymer form (procyanidins) [24]. When ACE was incubated with flavanol rich food extracts such as chocolates, tea and wine, a significant correlation between the ACE inhibition and the concentration of procyanidin and epicatechin was observed [30]. ACE inhibition by epicatechins of cocoa would be a reason for reported evidence for positive relationship between dark chocolate consumption and reduced high blood pressure [31]. The four major catechins, (-)-epicatechin, (-)-epigallocatechin, (-)-epicatechingallate and (-)epigallocatechingallate, isolated from tea had also shown a dose dependant ACE inhibition in a HUVEC culture model [32]. Pycnogenol, a procyanidin oligomer, isolated from French maritime pine (Pinus maritime) had also reported as an effective mediator for blood pressure regulation possibly by ACE inhibition [33]. These studies prove that among flavonoids, flavanols and procyanidins could also act as potent inhibitors of ACE in vitro.

The relationship between structure of flavanols and ACE inhibitory properties in vitro had been studied [34]. Increasing numbers of epicatechin units in the procyanidins had increased the enzyme inhibition [34]. When tested using HUVEC cell cultures, tetramer was the most effective enzyme inhibitor compared to dimer and hexamer of procyanidins [34]. The monomers of flavanols were found to be absorbed in the small intestine [35]. However, absorption of procyanidins with higher molecular weight has not clearly been reported. Though the tetramers were proved to be the most effective in vitro, the dimers are more effective in biological systems compared to both tetramers and hexamers [34].

\section{Flavonols}

Flavonols (Fig. 2) are reported to be the most ubiquitous flavonoid sub-group present in foods. Quercetin, kaempferol and myricetin are the three types of most common flavonols in our diet [24]. ACE inhibitory property of many flavonols has been reported. When a bioassay-guided fractionation of extract of stonecrop (Sedum sarmentosum) was performed, five purified flavonols were found to possess ACE inhibitory activity [36] (Table 1). Kaempferol-rich stem bark extracts of Cluster Fig (Ficus racemosa) has shown a dose dependant ACE inhibition property in vitro [37]. Based on an ex vivo experiment conducted using aortic tissues of male Wistar-Kyoto rats, kaempferol was found to be an effective ACE inhibitor but not resveratrol [38], a polyphenolic that is abundant in red wine. The presence of carbonyl group in the pyran ring of kaempferol is lacking in resveratrol and this could be a reason for the differences in their ACE inhibitory activity. However, when strawberry extracts rich in flavonoids were tested for ACE inhibition in vitro, no ACE inhibition was observed [39]. Aqueous extracts of Gingko biloba, which had quercetin derivatives as the major flavonoids, had higher ACE inhibitory activity than that of ethanol extracts [40]. The aqueous extracts of red currents (Ribes rubrum L.) and black currents (Ribes nigrum L.) exhibited ACE inhibition in vitro but not the extracts of red and green gooseberries (Ribes uva-crispa) [41]. The variation of differences in ACE inhibitory 
activity of plant extracts can be due to the presence of type of flavonoids and their concentration due to genetic differences of plant materials and the method of preparation of extracts, respectively.<smiles>C[C@H]1Cc2c(O)cc(O)cc2O[C@H]1c1ccc(O)c(O)c1</smiles>

Flavan-3-ol<smiles>O=c1c(O)c(-c2ccc(O)c(O)c2)oc2cc(O)cc(O)c12</smiles>

Flavonol<smiles>Oc1ccc(-c2[o+]c3cc(O)cc(O)c3cc2O)cc1</smiles>

Anthocyanidin<smiles>O=c1cc(-c2ccc(O)cc2)oc2cc(O)cc(O)c12</smiles>

Flavone

Fig. 2: Basic structures of selected major flavonoids

Flavonols act as prominent antioxidants in biological systems. Dietary quercetin supplementation at $730 \mathrm{mg} / \mathrm{d}$ for $28 \mathrm{~d}$ was found to be effective in reducing blood pressure in hypertensive patients in a randomized, double-blind, placebo-controlled, crossover study [42]. In another study, Captopril ${ }^{\circledR}$ and quercetin treatments have been given to male Wistar rats separately, whose hypertensive responses were triggered by angiotensin I and bradikinin ${ }^{\circledR}$ injections. Bradykinin is a physiologically active peptide that causes blood vessels to enlarge. Both treatments triggered the hypotensive responses significantly and quercetin was equally effective to Captopril when given orally or intravenously [43]. Significant reduction of plasma ACE due to quercetin pretreatment $(88.7 \mu \mathrm{mol} / \mathrm{kg})$ was reported in this animal study. In contrast, chronic treatment of quercetin aglyconee that was given at $10 \mathrm{mg} / \mathrm{kg}$ intraperitoneally for $14 \mathrm{ds}$ to rats, did not inhibit plasma ACE activity with compared to the control group [44].

$\mathrm{ACE}$ is found to be involved in plasma protein extravasation (PE), which is an important component in neurogenic inflammation [45]. It is known that PE can be evoked by substance P which is hydrolyzed by ACE. Similar to the action of Captopril, dietary supplementation of quercetin can potentiate plasma $\mathrm{PE}$ induced by substance $\mathrm{P}$ in rat urinary bladder possibly by 
inhibition of the peptidase which hydrolyze substance $\mathrm{P}$ [46]. From the reviewed literature, flavonols showed potential ACE inhibition both in vitro and in vivo. However, since flavonols are known to produce sulfate, glucuronide and methylated metabolites in vivo [47], ACE inhibition by quercetin metabolites in vitro required further investigation.

\section{Isoflavones}

Isoflavones are unique flavonoids as they exhibit structural similarity to mammalian estrogen hormone. They can effectively bind to the estrogen receptors and often called as phytoestrogens [48]. Genistein, daidzein and glycetin are the common isoflavones present in plants ([24]. Among them, genistein is the prominent isoflavone widely investigated on health promoting effects. The major isoflavone in soybean is genistein [49]. Genistein has been reported for reducing blood pressure in animal models. For example, genistein has decreased NaCl-sensitive hypertension in stroke-prone spontaneously hypertensive rats [50]. Genistein dose-dependently decreased ACE gene expression and enzyme activity in rat aortic endothelial cells (RAEC). serum and aorta tissue [51]. However, the exact mechanisms for this modulation were not fully understood. $\mathrm{Xu}$ and co-workers (2006) found that genistein dose-dependently decreased ACE gene expression and enzyme activity in rat aortic endothelial cells (RAEC), serum and aorta tissue. The effect was mediated by estrogen receptor and subsequent activation of the ERK1/2 signaling pathway in RAEC. In vitro studies showed a concentration dependant ACE inhibition by genistein which was confirmed by others [52]. However, the presence of isoflavones in ACE inhibitory soybean peptide fractions had not shown any enhanced enzyme inhibitory effect when compared with the peptide fractions without isoflavones. Studies had conducted using animal models to investigate the in vivo activity of isoflavones. Pretreatment of single intravenous injection dose of genistein $25 \mathrm{mg} / \mathrm{kg}$ had shown reduced hypertensive responses in hypertensive Wistar rats. The reduced hypertension was associated with significant reduction of ACE activity in rat plasma [52]. Another in vivo study had proved that genistein can down regulate the ACE producing gene expression by interfering with cell signaling pathways [51]. However, there are no related studies on two other soybean isoflavones, daidzein and glycetin, on ACE inhibitory effect.

\section{Flavones}

There is less information on ACE inhibitory properties of flavones when compared to the other types of flavonoids. However, extracts of Roxb (Ailanthus excelsa), Japanese cedar (Cryptomeria japonica), (H. sabdariffa) and Senecio species (Compositae) which comprise of flavones have shown the ACE inhibitory property [21,53]. The two major flavones of Roxb, apigenin and luteolin, have shown a dose dependant enzyme inhibition. Compared to luteolin aglyconee, luteolin-7-O-glucoside had shown a reduced enzyme activity comprising to a higher $\mathrm{IC}_{50}$ value (Table 1) [21]. The loss of hydroxyl group at $7^{\text {th }}$ position could be the reason for the decreased enzyme inhibition by the glycoside. The ethanol extracts of the outer bark of Japanese 
cedar has inhibited $\mathrm{ACE}$ in vitro and resulted an $\mathrm{IC}_{50}$ value of $16 \mu \mathrm{g} / \mathrm{mL}$. The extract was rich in flavan-3-ols and flavones. The enzyme inhibitory effect would be a result of the synergistic effect of all compounds present in the extract [54]. Crude hydroalcoholic extract rich in flavones from $H$. sabdariffa had shown satisfactory enzyme inhibition on ACE but not elastase, trypsin and alpha-chymotrypsin [55]. As all the studies discussed were investigating the effect of plant extracts containing flavones, the inhibitory effect could also be due to other constituents of the extract. Specific focus on isolated flavone compounds and their ACE inhibitory activity can generate valuable information about the flavones with ACE inhibition properties.

\section{Other flavonoids}

Chalcones are precursor molecules of the biosynthetic pathways of flavonoids [23]. These consist of two phenyl rings joined by a three carbon open chain. There are numerous evidences on beneficial pharmacological properties of chalcones. Chalcones and their pyrazole derivatives inhibited ACE in a concentration dependent manner in vitro [56]. Butein, a chalcone, supplementation through intravenous injection has been found to reduce the arterial blood pressure in anesthetized normotensive rats [20]. The ACE activities were found to be decreased in a dose dependant manner; however, the value of butein seems to be significantly greater than other flavonoids (Table 1).

\section{Structurally modified flavonoids}

In general, most of the phytochemicals including flavonoids are shown more effective beneficial pharmacological properties in vitro than in vivo. This could be due to several reasons including low bioavailability, lack of stability, poor membrane penetration, lack of site specific distribution and rapid elimination of these flavonoids [57]. Introducing structural modifications to flavonoids were found to be effective in enhancing some biological functionality of parent flavonoids. The methylated form of tea catechins had been found as effective ACE inhibitors. The methylated molecule epigallocatechin-3-O-(3-O-methyl)gallate had shown higher inhibition on ACE than epigallocatechin-3-O-gallate [58]. The results of the above mentioned study prove that structural modification of some flavonoids could offer a greater potential to use them as more effective ACE inhibitors.

\section{Comparison of $\mathrm{IC}_{50}$ Values of Flavonoids}

The $\mathrm{IC}_{50}$ values for ACE of most of reported flavonoids have summarized (Table 1). We have investigated the $\mathrm{IC}_{50}$ values of quercetin, quercetin-3-glucoside, quercetin-3-galactoside and cyanidin-3-galactoside which were $151 \mu \mathrm{M}, 71 \mu \mathrm{M}, 180 \mu \mathrm{M}, 206 \mu \mathrm{M}$, respectively (Balasuriya and Rupasinghe, unpublished). The values fall within the range of $\mathrm{IC}_{50}$ values reported for other flavonoid compounds. Further we investigated the ACE inhibition of some selected flavonoid metabolites. Among the metabolites tested quercetin-3-glucuronic acid showed successful inhibition for ACE. Interestingly, the metabolite was the most effective when compared with all 
other tested compounds, giving an $\mathrm{IC}_{50}$ value of $27 \mu \mathrm{M}$. When compared to quercetin-3glucoside, the presence of carboxylic acid group in the glucuronide, seems to contribute to the inhibition of ACE.

Some of the reported studies had focused on ACE inhibitory property of plant extracts. Table 2 summarizes the $\mathrm{IC}_{50}$ values of effective plant extracts on ACE inhibition. In our study, a flavonoid-rich apple peel extract rich in flavonoids shows an $\mathrm{IC}_{50}$ of $49 \mu \mathrm{M}$ (Balasuriya and Rupasinghe, unpublished). Compared to other plant extracts reported, apple peel extract is an effective ACE inhibitor. When compared to all the reviewed flavonoid compounds, quercetin metabolites and plant extracts with the drugs (Table 3), none of the flavonoids or the extracts showed similar $\mathrm{IC}_{50}$ values of the drugs. It is convincing that naturally occurring flavonoids are not potent treatments for hypertension but could offer promise for reducing the hypertension at early or mid stages of the risk.

Table 1: $\mathrm{IC}_{50}$ values of ACE inhibitory flavonoids and their metabolites.

\begin{tabular}{|c|c|c|c|}
\hline $\begin{array}{l}\text { Group of } \\
\text { Flavonoids }\end{array}$ & Compound & $\mathrm{IC}_{50}$ Value & Reference \\
\hline \multirow[t]{3}{*}{ Anthocyanins } & Delphinidin-3-O-sambubioside & $142 \mu \mathrm{M}$ & [6] \\
\hline & Cyanidin-3-O-sambubioside & $118 \mu \mathrm{M}$ & {$[6]$} \\
\hline & Cyanidin-3-O- $\beta$-glucoside & $139 \mu \mathrm{M}$ & {$[27]$} \\
\hline \multirow[t]{3}{*}{ Flavones } & Apigenin & $280 \mu \mathrm{M}$ & {$[21]$} \\
\hline & Luteolin & $290 \mu \mathrm{M}$ & {$[21]$} \\
\hline & Luteolin-7- $O$-glucopyranoside & $280 \mu \mathrm{M}$ & {$[21]$} \\
\hline \multirow[t]{8}{*}{ Flavonols } & Quercetin glucuronide & $200 \mu \mathrm{M}$ & {$[60]$} \\
\hline & Quercetin-3-O-(6"'-galoyl)-galactoside & $160 \mu \mathrm{M}$ & {$[60]$} \\
\hline & $\begin{array}{c}\text { Quercetin-3-O- } \alpha-\left(6^{\prime \prime \prime} \text {-caffeoylglucosyl- }\right. \\
\beta-1,2-\text { rhamnoside })\end{array}$ & $159 \mu \mathrm{M}$ & {$[36]$} \\
\hline & $\begin{array}{l}\text { Quercetin-3-O- } \alpha-\left(6^{\prime \prime \prime}-p-\right. \\
\text { coumaroylglucosyl- } \beta-1,2-\text { rhamnoside })\end{array}$ & $352 \mu \mathrm{M}$ & {$[36]$} \\
\hline & Isorhamnetin-3- $\beta$-glucopyranoside & $409 \mu \mathrm{M}$ & {$[36]$} \\
\hline & Quercetin-3- $\beta$-glucopyranoside & $709 \mu \mathrm{M}$ & {$[36]$} \\
\hline & Quercetin-3- $\alpha$-arabinopyranoside & $310 \mu \mathrm{M}$ & {$[21]$} \\
\hline & Kaempferol-3- $\alpha$-arabinopyranoside & $393 \mu \mathrm{M}$ & {$[36]$} \\
\hline \multirow[t]{2}{*}{ Flavan-3-ols } & Epicatechin - dimer & $97 \mu \mathrm{M}$ & [34] \\
\hline & Epicatechin - tetramer & $4 \mu \mathrm{M}$ & {$[34]$} \\
\hline
\end{tabular}


Epicatechin - hexamer

Chalcones Butein

Flavonoid Quercetin-3-O-glucuronic acid metabolites
$8 \mu \mathrm{M}$

$730 \mu \mathrm{M}$

[20]

$27 \mu \mathrm{M}$

Balasuriya and

Rupasinghe

(Unpublished)

Table 2: ACE inhibition ( $\mathrm{IC}_{50}$ Values) by various plant extracts

\begin{tabular}{|c|c|c|}
\hline Plant Extracts & $\mathrm{IC}_{50}$ Value & Reference \\
\hline Hibiscus sabdariffa (Hibiscus) & $91 \mu \mathrm{g} / \mathrm{mL}$ & {$[6]$} \\
\hline Camelia synensis (green tea) & $125 \mu \mathrm{g} / \mathrm{mL}$ & [61] \\
\hline $\begin{array}{l}\text { Vaccinium ashei reade (Blueberry leaf } \\
\text { extract) }\end{array}$ & $46 \mu \mathrm{g} / \mathrm{mL}$ & {$[61]$} \\
\hline Vaccinium myrtillus (Bilberry) & $\begin{array}{ll}\log & -2.6 \\
\mathrm{mg} / \mathrm{mL}\end{array}$ & {$[28]$} \\
\hline $\begin{array}{l}\text { Senecio inaequidens } \\
\text { (A perennial herb) }\end{array}$ & $192 \mu \mathrm{g} / \mathrm{mL}$ & {$[53]$} \\
\hline $\begin{array}{l}\text { S. ambiguous subsp. Ambigus } \\
\text { (ethyl acetate extract) }\end{array}$ & $219 \mu \mathrm{g} / \mathrm{mL}$ & {$[53]$} \\
\hline $\begin{array}{l}\text { S. ambiguous subsp. Ambigus } \\
\text { (n-hexane extract) }\end{array}$ & $307 \mu \mathrm{g} / \mathrm{mL}$ & {$[53]$} \\
\hline Cryptomeria japonica (Japanese Cedar) & $16 \mu \mathrm{g} / \mathrm{mL}$ & {$[54]$} \\
\hline $\begin{array}{l}\text { Malus domestica } \\
\text { (Apple skin ethanol extract) }\end{array}$ & $49 \mu \mathrm{g} / \mathrm{mL}$ & $\begin{array}{l}\text { Balasuriya and Rupasinghe } \\
\text { (Unpublished) }\end{array}$ \\
\hline
\end{tabular}

Table 3: $\mathrm{IC}_{50}$ Values of ACE for Antihypertensive Drugs

\begin{tabular}{|c|c|c|}
\hline Drug & $\mathrm{IC}_{50}$ Value & Reference \\
\hline Captopril $^{(B)}$ & $0.02 \mu \mathrm{M}$ & [36] \\
\hline Lisinopril $^{(\mathbb{B}}$ & $1.8 \mu \mathrm{M}$ & [6] \\
\hline
\end{tabular}

\section{Enzyme Kinetic Studies}

Some of the studies have focused on finding the type of enzyme inhibition of flavonoids. All compounds studied were in accordance with the Michaelis-Menten theorem. Anthocyanins have shown competitive type inhibition over ACE. Delphinidin-3-O-sambubioside, cyanidin-3-O- 
sambubioside, and anthocyanin rich fractions from Hibiscus species were among the samples studied [6]. In a kinetic study conducted to find the effect of dimmers and tetramers of procyanidins at the presence of chloride ions on ACE had found a competitive type enzyme inhibition irrespective of the presence of chloride ions [34]. The dimmers and hexamers of the epicatechins were found to be competitive inhibitors. The inhibition over two types of substrates (HHL and FAPGG) was studied and no difference was observed depending on the substrate [7]. Most flavonoids were reported to be competitive type inhibitors meaning that they can compete with the substrate in binding to the active site of the enzyme. A group of condensed tannins (procyanidin B-5 3,3'-di- $O$-gallate and procyanidin C-1 3,3',3"-tri- $O$-gallate) isolated from Rhei rhizoma had shown reversible and non competitive type of inhibition over ACE. The inhibitory kinetic were determined using Dixon plots [59]. There is not much evidence associated with the enzyme kinetics of specific flavonoids compared to other types of natural ACE inhibitors like plant and fish peptides. To the best of our knowledge, only flavan-3-ols and anthocyanins were the two flavonoid groups that were found to used for the enzyme kinetics studies.

\section{Summary}

Flavonoids are one of the major groups of plant secondary metabolites, with numerous beneficial pharmacological properties. Their recognition as effective biomolecules had made the scientists to investigate the potential use of flavonoids and flavonoid-rich extracts as natural ACE inhibitors, where the ACE activity is identified as a critical factor in regulating high blood pressure. All most all the subcategories of flavonoids were studied on ACE inhibitory activity. Though the $\mathrm{IC}_{50}$ values for $\mathrm{ACE}$ are very greater for flavonoids when compared with antihypertensive drugs, the most of the flavonoids are found to be competitive inhibitors of ACE.

Among flavonoids, flavan-3-ols and anthocyanins are effective ACE inhibitors in vitro as well as in animal model system. Catechins and their polymers proved to be the most effective ACE inhibitor in vitro. However, the results of the in vitro studies may not reflect exactly the outcome of in vivo studies. Therefore, further studies using animal models are required to confirm their ACE inhibitory properties. Isoflavones are showing intermediary inhibition towards ACE. Flavonols had proved to be less effective in vitro but in animal studies they were found to be more effective. Fewer studies had been conducted on flavones and chalcones. Structurally modified flavonoids designed for greater absorption and bioavailability could have a higher potential in use as ACE inhibitors. In terms of the mode of action, flavonoids had shown competitive type inhibition for ACE.

In conclusion, naturally occurring flavonoids have a potential to be used as mild or moderate $\mathrm{ACE}$ inhibitors. As the $\mathrm{IC}_{50}$ values of flavonoids were higher than that of the prescribed drugs for hypertension, flavonoids could be used as preventative nutraceuticals over hypertension rather than using as therapeutic drug for hypertension. Flavonoid-derived natural health products could become popular among patients with mild hypertension as well as the patients who have adverse side effects for currently available antihypertensive drugs. Future 
research should also be focused on structural modifications of flavonoids and their antihypertensive properties.

Abbreviations: Angiotensin converting enzyme (ACE), Hippuryl- ${ }_{L}-$ histidyl-$_{-}-{ }_{-}$eucine (HHL), N-(3-[2-furyl]acryloyl-phenylala glycy L glycine (FAPGG), High performance liquid chromatography (HPLC)

\section{Authors' contributions}

H.P. Vasantha Rupasinghe, $\mathrm{PhD}$. is the principle investigator for this study providing oversight and contributed fundamental conceptualization for the research. E-mail: vrupasinghe@nsac.ca B.W. Nileeka Balasuriya, M.Sc. is a graduate student who has performed all of the experiments reported in this manuscript. E-mail: nbalasuriya@nsac.ca.

\section{Acknowledgement and Funding}

The financial support for this study was provided by the Discovery Grant program of the Natural Science and Engineering Research Council (NSERC) of Canada. The authors would like to greatly acknowledge the generous supply of quercetin metabolites for this study by Dr. Paul Kroon of the Institute of Food Research, Norwich Research Park, Colney, Norwich, UK.

\section{References}

1. Mittal BV, Singh AK. Hypertension in the developing world: challenges and oppurtunities. Am J Kidney Dis 2010; 55(3):590-8.

2. Oparil MD, Zaman MA, Calhoun DA. Pathogenesis of hypertension. Ann Intern Med 2003; 139:761-76.

3. Hammoud RA, Vaccari CS, Nagamia SH, Khan BV. Regulation of the renin-angiotensin system in coronary atherosclerosis: a review of the literature. Vasc Health Risk Manag 2007; 3(6):93745.

4. Israili $\mathrm{ZH}$, Hall WD. Cough and angioneurotic edema associated with angiotensin-converting enzyme inhibitor therapy. A review of the literature and pathophysiology. Ann Inter Med 1992; 117(3):234-42.

5. Cinq-Mars CD, Li-Chan ECY. Optimizing angiotensin 1-converting enzyme inhibitory activity of Pacific Hake (Merluccius productus) fillet hydrolysate using response surface methodology and ultrafiltration. J Agric Food Chem 2007; 55 (23):9380-8.

6. Ojeda D, Jiménez-Ferrer E, Zamilpa A, Herrera-Arellano A, Tortoriello J, Alvarez L. Inhibition of angiotensin converting enzyme (ACE) activity by the anthocyanins delphinidin- and cyanidin3-O-sambubiosides from Hibiscus sabdariffa. J Ethnopharmacol 2010; 127(1):7-10.

7. Actis-Goretta L, Ottaviani JI, Keen CL, Fraga CG. Inhibition of angiotensin converting enzyme (ACE) activity by flavan-3-ols and procyanidins. FEBS Lett 2003; 555(3):597-600. 
8. Somova LO, Nadar A, Rammanan P, Shode FO. Cardiovascular, antihyperlipidemic and antioxidant effects of oleanolic and ursolic acids in experimental hypertension. Phytomedicine 2003; 10(2-3):115-21.

9. Ortiz-Salmerón E, Barón C, García-Fuentes L. Enthalpy of captopril-angiotensin I-converting enzyme binding. FEBBS Lett 1998; 435(2-3):219-24.

10. Alves MF, Arajujo MC, Juliano MA, Oliveira EM, Krieger JE, Casarini DE, Juliano L, Carmona AK. A continuous florescent assay for the determination of plasma and tissue angiotensin I converting enzyme activity. Braz J Med Biol Res 2005; 38(6):861-8.

11. Lahogue V, Réhel K, Taupin L, Haras D, Allaume P. A HPLC-UV method for the determination of angiotensin I-converting enzyme (ACE) inhibitory activity. Food Chem 2010; 118(3):870-5.

12. Udenigwe CC, Lin YS, Hou WC, Aluko RE. Kinetics of the inhibition of renin and angiotensin I-converting enzyme by flaxseed protein hydrolysate fractions. J Func Foods 2009.1(2):199-207.

13. Wu J, Aluko RE, Muir AD. Purification of angiotensin I-converting enzyme peptides from the enzymatic hydrolysate of defatted canola meal. Food Chem 2008; 111(4):942-50.

14. Sentandreu MA, Toldrá F. A rapid, simple and sensitive fluorescence method for the assay of angiotensin-I converting enzyme. Food Chem 2006; 97:546-54.

15. Hong F, Ming L, Yi S, Zhanxia L, Yongquan W, Chi L. The antihypertensive effect of peptides: A novel alternative to drugs? Peptides 2008; 29(6):1062-71.

16. Yamamoto N. Antihypertensive peptides derived from food proteins. Biopolymers 1997; 43(2):129-34.

17. Vercruysse L, Camp JV, Smagghe G. ACE inhibitory peptides derived from enzymatic hydrolysates of animal muscle protein: a review. J Agric Food Chem 2005; 53(21):8106-15.

18. Farzamirad V, Aluko RE. Angiotensin-converting enzyme inhibition and free-radical scavenging properties of cationic peptides derived from soybean protein hydrolysates. Int J Food Sci Nutr 2008; 59(5) 428-37.

19. Guang C, Phillips RD. Plant food-derived angiotensin I converting enzyme inhibitory peptides. J Agric Food Chem 2009; 57(12):5113-20.

20. Kang DG, Kim YC, Sohn EJ, Lee YM, Lee AS, Yin MH, Lee HS. Hypotensive effect of butein via inhibition of angiotensin converting enzyme. Biol Pharm Bull 2003; 26(9):1345-7.

21. Loizzo MR, Said A, Tundis R, Rashed K, Statti GA, Hufner A, Menichini F. Inhibition of angiotensin converting enzyme (ACE) by flavonoids isolated from Ailanthus excels (Roxb) (Simaroubaceae). Phytother Res 2007; 21:32-6.

22. Croft KD. The chemistry and biological effects of flavonoids and phenolic acids. Ann N Y Acad Sci 1998; 854:435-42.

23. Rupasinghe HPV. The role of polyphenols in quality, postharvest handling and processing of fruits. Ed: Paliyath G, Lurie S, Murr D. Handa A. Postharvest Biology and Technology of Fruits, Vegetables, and Flowers. Wiley-Blackwell Publishers. 2008; pp 260-81.

24. D’Archivio M, Filesi C, Benedetto RD, Gargiulo R, Giovannini C, Masella R. Polyphenols, dietary sources and bioavailability. Ann $1^{\text {st }}$ Super Sanita 2007; 43(4):348-61. 
25. Stevenson DE, Hurst RD. Polyphenolic phytochemicals -- just antioxidants or much more? Cell Mol Life Sci 2007; 64(22):2900-16.

26. Soundararajan R, Wishart AD, Rupasinghe HPV, Arcellena-Panlilio M, Nelson CM, Mayne M, Robertson GS. Quercetin 3-glucoside protects neuroblastoma (SH-SY5Y) cells in vitro against oxidative damage by inducing sterol regulatory element-binding protein-2-mediated cholesterol biosynthesis. J Biol Chem 2008; 284(4):2231-45.

27. Kwon EK, Lee DY, Lee H, Kim DO, Baek NI, Kim YE, Kim HY. Flavonoids from the buds of Rosa damascena inhibit the activity of 3-hydroxy-3-methylglutaryl-coenzyme a reductase and angiotensin I-converting enzyme. J Agric Food Chem 2010; 58(2):882-6.

28. Persson IAL, Persson K, Andersson RGG. Effect of Vaccinium myrtillus and its polyphenols on angiotensin-converting enzyme activity in human endothelial cells. J Agric Food Chem 2009; 57(11):4626-29.

29. Shindo M, Kasai T, Abe A, Konido Y. Effects of dietary administration of plant-derived anthocyanin-rich colours to spontaneously hypertensive rats. J Nutr Sci Vitaminol 2007; 53(1):90-3.

30. Actis-Goretta L, Ottaviani JI, Fraga CG. Inhibition of angiotensin converting enzyme activity by flavanol-rich foods. J Agric Food Chem 2006; 54(1):229-34.

31. Egan BM, Laken MA, Donovan JL, Woolson RF. Does dark chocolate have a role in the prevention and management of hypertension? Commentary on the evidence. Hypertension 2010; 55:1289-95.

32. Persson IA, Joseffsson M, Persson K, Anderson RG. Tea flavanols inhibit angiotensinconverting enzyme activity and increase nitric oxide production in human endothelial cells. $\mathrm{J}$ Pharm Pharmacol 2006; 58(8):1139-44.

33. Zibadi S, Rohdewald PJ, Park D, Watson RR. Reduction of cardiovascular risk factors in subjects with type 2 diabetes by Pycongenol supplementation. Nutr Res 2008; 28:315-20.

34. Ottaviani JI, Actis-Goretta L, Villordo JJ, Fraga CG. Procyanidin structure defines the extent and specificity of angiotensin I converting enzyme inhibition. Biochimie 2006; 88:359-65.

35. García-Cornesa MT, Tribolo S, Guyot S, Tomás-Barberán FA, Kroon PA. Oligomeric procyanidins inhibit cell migration and modulate the expression of migration and proliferation associated genes in human umbilical vascular endothelial cells. Mol Nutr Food Res 2009; 53(2):266-76.

36. Oh H, Kang DG, Kwon JW, Kwon TO, Lee SY, Lee DB, Lee HB. Isolation of angiotensin converting enzyme (ACE) inhibitory flavonoids from Sedum sarmentosum. Biol Pharm Bull 2004; 27:2035-7.

37. Ahmed F, Siddesha JM, Urooj A, Vishwanath BS. Radical scavenging and angiotensin converting enzyme inhibitory activities of standardized extracts of Ficus racemosa stem bark. Phytother Res 2010; 24(12):1839-43. 
38. Olszanecki R, Bujak-Gizycka B, Madej J, Suski M, Wolkow PP, Jawién J, Korbut R. Kaempferol, but not resveratrol inhibits angiotensin converting enzyme. J Physiol Phamacol 2008; 59:(2)387-92.

39. Pinto MD-S, Kwon YI, Apostolidis E, Lajolo FM, Genovese MI, Shetty K. Functionality of bioactive compounds in Brazilian strawberry (Fragaria $\mathrm{x}$ ananassa Duch.) cultivars: evaluation of hyperglycemia and hypertension potential using in vitro models. J Agric Food Chem 2008; 56(12):4386-92.

40. Pinto MD-S, Kwon YI, Apostolidis E, Lajolo FM, Genovese MI, Shetty K. Potential of Ginkgo biloba $L$. leaves in the management of hyperglycemia and hypertension using in vitro models. Bioresource Technol 2009; 100(24):6599-6609.

41. Pinto MD-S, Kwon YI, Apostolidis E, Lajolo FM, Genovese MI, Shetty K. Evaluation of red currants (Ribes rubrun L.) black currents (Ribes nigrum L.) red and green gooseberries (Ribes uva-crisp A) for potential management of type 2 diabetes and hypertension using in vitro models. J Food Biochem 2010; 34:639-60.

42. Edwards RL, Lyon T, Litwin SE, Rabovsky A, Symons JD, Jalili T. Quercetin reduces blood pressure in hypertensive subjects. J Nutr 2007; 137:2405-11.

43. Häckl LPN, Cuttle G, Dovichi SS, Lima-Landman MT, Nicolau M. Inhibition of angiotensin converting enzyme by quercetin alters the vascular response to bradykinin and angiotensin I. Pharmacol 2002; 65:182-6.

44. Neto-Neves EM, Montenegro MF, Dias-Junior CA, Spiller F, Kanashiro A, Tanus-Santos JE. Chronic treatment with quercetin does not inhibit angiotensin-converting enzyme in vivo or in vitro. Basic Clin Pharmacol Toxicol 2010; 107(4):825-9.

45. Wille PR, Ribeiro-do-Valle RM, Simões CMO, Gabilan NH, Nicalou M. Effect of quercetin on tachykinin-induced plasma extracvasation in rat urinary bladder. Phytother Res 2001; 15(5):4446.

46. Nicolau M, Dovichi SS, Cuttle G. Pro-inflammatory effect of quercetin by dual blockade of angiotensin converting-enzyme and neutral endopeptidase in vivo. Nutr Neurosci 2003; 6(5):30916.

47. Rupasinghe HPV, Ronalds CM, Rathgeber B, Robinson RA. Absorption and tissue distribution of dietary quercetin and quercetin glycosides of apple skin in broiler chickens. J Sci Food Agric 2010; 90(7):1172-8.

48. Jackson CJC, Rupasinghe HPV. Food sources and composition of phytoestrogens. In: Phytoestrogens and Health (Ed.) Messina M, AOCS Press, Champaign, IL, USA. 2002; pp. 95123.

49. $\mathrm{Wu}$ J, Muir AD. Isoflavone content and its potential contribution to the antihypertensive activity in soybean angiotensin I converting enzyme inhibitory peptides. J Agric Food Chem 2008; 56(21):9899-904. 
50. Cho TM, Peng N, Clark JT, Novak L, Roysommuti S, Prasain J, Wyss JM. Genistein attenuates the hypertensive effects of dietary $\mathrm{NaCl}$ in hypertensive male rats. Endocrinology 2007; 148(11):5396-402.

51. Xu YY, Yang C, Li SN. Effects of genistein on angiotensin-converting enzyme in rats. Life Sci 2006; 79(9):828-37.

52. Montenegro MF, Pessa LR, Tanus-Santos JE. Isoflavone genistein inhibits the angiotensin converting enzyme and alters the vascular responses to angiotensin I and bradykinin. Eur J Pharmacol 2009; 607(1-3):173-177.

53. Loizzo MR, Tundis R, Conforti F, Statti GA, Menichini F. Inhibition of angiotensin converting enzyme activity by Senecio Species. Pharm Biol 2009; 47(6):516-20.

54. Tsutsumi Y, Shimada A, Miyano A, Nishida T, Mitsunaga T. In vitro screening of angiotensin Iconverting enzyme inhibitors from Japanese cedar (Crptomera japonica). J Wood Sci 1997; 44(6):463-8.

55. Jonadet M, Bastide J, Bastide P, Boyer B, Carnat AP, Lamaison JL. In vitro enzyme inhibitory and in vivo cardioprotective activities of hibiscus (Hibiscus sabdariffa L.). J Pharm Belg 1990; 45(2):120-4.

56. Bonsei M, Loizzo MR, Statti GA, Michel S, Tillequin F. The synthesis and angiotensin converting enzyme (ACE) inhibitory activity of chalcones and their pyrazole derivatives. Bioorg Medicinal Chem Lett 2010; 20(6):1990-3.

57. Srinivas NR. Structurally modified 'dietary flavonoids': are these viable drug candidates for chemoprevention? Curr Clin Phamacol 2009; 4(1):67-70.

58. Kurita I, Yamamoto MM, Tachibanas H, Kamei M. Antihypertensive effect of Benifuuki tea containing O-methylated EGCG. J Agric Food Chem 2010; 58(3):1903-8.

59. Uchida S, Ikari N, Ohta M, Niwa M, Nonaka G, Nishioka I, Ozaki M. Inhibitory effects of condensed tannins on angiotensin converting enzyme. Jpn J Phamacol 1987; 43(2):242-6.

60. Kiss A, Kowalski J, Melzig MF. Compounds from Epilobium angustifolium inhibit the specific metallopeptidases ACE, NEP, and APN. Planta Med 2004; 70(10):919-23.

61. Sakaida H, Nagao K, Higa K, Shirouchi B, Inoue N, Hidaka F, Kai T, Yanagita T. Effect of Vaccinium ashei reade leaves on angiotensin converting enzyme activity in vitro and systolic blood pressure of spontaneously hypertensive rats in vivo. Biosci Biotechnol Biochem 2007; 71(9):2335-7 